\title{
Aleksandra Guss
}

Uniwersytet Gdański

aleksandra.guss@phdstud.ug.edu.pl

ORCID: https://orcid.org/0000-0002-4157-6853

\section{Lista Skarbów Dziedzictwa - niepotrzebna forma ochrony zabytków?}

\author{
http://dx.doi.org/10.12775.SIT.2021.022
}

\section{Wprowadzenie}

W ostatnim czasie dostrzegalna jest tendencja prawodawcy do zapewnienia wzmożonej i efektywnej ochrony zabytków poprzez stopniowe poszerzanie katalogu form ich ochrony, uregulowanego w Ustawie $z$ dnia 23 lipca 2003 r. o ochronie zabytków i opiece nad zabytkami ${ }^{1}$ (dalej: u.o.z.). Można tu nawet mówić o swego rodzaju zjawisku ewolucji w stosunku do kategorii prawnych form ochrony zabytków, czyli o permanentnym i progresywnym procesie polegającym na ich stopniowym poszerzaniu i optymalizacji ${ }^{2}$. Nowe rozwiązania nie zawsze są jednak trafne i często okazuje się, że mijają się $z$ celem, jaki miał pierwotnie ustawodawca - zarówno z tym jawnie deklarowanym, jak i z celami nierzadko ukrytymi. Taka sytuacja zachodzi w przypadku wpisu zabytku na Listę Skarbów Dziedzictwa.

Lista Skarbów Dziedzictwa jest stosunkowo nową formą ochrony zabytków, wprowadzoną bowiem do ustawy nowelizacją z 2016 r.

${ }^{1}$ Dz.U. z 2003 r. Nr 162, poz. 1568 ze zm.

2 P. Dobosz, Ewoluujace prawne formy ochrony zabytków $w$ Polsce, w: Prawo ochrony zabytków, red. K. Zeidler, Warszawa-Gdańsk 2014, s. 219. 
i mającą dwojakie korzenie. $Z$ jednej strony, zgodnie $z$ uzasadnieniem projektu, Lista została stworzona w celu zapewnienia możliwości prowadzenia bardziej skutecznej polityki ochrony zabytków w skali całego kraju poprzez ustanowienie specjalnych instrumentów ochrony najcenniejszych dóbr kultury, które znajdują się w zbiorach publicznych i poza nimi ${ }^{3}$. Nie da się ukryć, że w odniesieniu do zabytków ruchomych mamy do czynienia $z$ sui generis ich dyskryminacją, ponieważ są one objęte mniejszą liczbą form ochrony niż zabytki nieruchome i w dodatku ochrona ta aktywuje się w zasadzie na wniosek właściciela zabytku.

$Z$ drugiej strony, idea Listy Skarbów Dziedzictwa wyrosła na gruncie sporów, które przez wiele lat toczyły się między muzealnikami, konserwatorami i historykami sztuki a Fundacją Czartoryskich z powodu wypożyczania obrazu Leonarda da Vinci Dama z łasicz$k a$, na którym fundacja zarabiała, przy równoczesnym unikaniu kosztów utrzymania dzieła, które ponosiło Muzeum Narodowe w Krakowie ${ }^{4}$. Kontrowersje wzbudzała nie tylko sama geneza Listy Skarbów Dziedzictwa, ale również przepisy jej dotyczące, których zgodność z przepisami Konstytucji RP podano w wątpliwość.

Krytyczny obraz Listy Skarbów Dziedzictwa dopełniany jest problemem jej funkcjonowania w praktyce, a raczej braku funkcjonowania. Jak wynika $z$ Rozporządzenia Ministra Kultury i Dziedzictwa Narodowego z dnia 28 kwietnia 2017 r. w sprawie Listy Skarbów Dziedzictwa ${ }^{5}$, Lista ta prowadzona jest w systemie teleinformatycznym udostępnionym w Biuletynie Informacji Publicznej na stronie Ministra Kultury i Dziedzictwa Narodowego (§ 2), jednak po wejściu na stronę Biuletynu na próżno jej tam szukać, ponieważ Listy finalnie nie utworzono. Istnieje ona tylko jako teoretyczny

${ }^{3}$ Druk sejmowy nr 3112, Sejm VII kadencji, s. 2 i n.

4 Zob. MKiDN: przepisy nie chroniły integralności całej kolekcji Czartoryskich, https://dzieje.pl/kultura-i-sztuka/mkidn-przepisy-dot-listy-skarbow-dziedzictwa-nie-chronily-integralnosci-calej-kolekcji (dostęp: 19.06.2021 r.); http://www.magazynsztuki.pl/dama-z-lasiczka-na-linii-sporu/ (dostęp: 19.06.2021 r.); https://www.rp.pl/Prawo-dla-Ciebie/312149921-Kamil-Zeidler-o-odkupieniu-od-Fundacji-Ksiazat-Czartoryskich-prawa-do-kolekcji-dziel-sztuki-zgromadzonych-w-Krakowie.html (dostęp: 19.06.2021 r.).

${ }^{5}$ Dz.U. poz. 928. 
instrument ochrony w ustawie o ochronie zabytków, czyli jest tzw. martwym prawem. W związku z powyższym pojawia się pytanie, czy jest to forma w ogóle potrzebna w polskim systemie prawnej ochrony zabytków i czy przypadkiem ochrona cennych dóbr kultury nie jest już realizowana w inny, efektywny sposób.

\section{Prawne formy ochrony zabytków w Polsce i ich ewolucja}

O tym, jak ważne jest zapewnienie odpowiedniej ochrony dziedzictwu kultury, polski ustawodawca wie już od dawna. Pierwszym aktem prawodawczym, którego celem była ochrona narodowego dziedzictwa kultury, był Dekret Rady Regencyjnej Królestwa Polskiego z dnia 31 października 1918 r. o opiece nad zabytkami sztuki i kultury ${ }^{6}$, wydany jeszcze przed formalnym odzyskaniem niepodległości przez Polskę. Choć może się wydawać, że w tak burzliwym i intensywnym politycznie okresie kwestie ochrony dziedzictwa kultury były drugo- czy nawet trzeciorzędne, to właśnie materialny dorobek narodu polskiego stanowił jego spoiwo oraz pozwolił Polakom przetrwać najtrudniejsze czasy pod zaborami i $z$ tego też powodu zapewnienie mu odpowiedniej ochrony prawnej potraktowano priorytetowo ${ }^{7}$.

Dekret stanowił fundament kształtowania się systemu ochrony zabytków w Polsce. Jak wskazał Jan Pruszyński, wiele rozwiązań sformułowanych w tym akcie wyprzedzało metody przyjęte za granicą i zachowało aktualność do dzisis . Pierwszą formą ochrony wprowadzoną w dekrecie był wpis do inwentarza zabytków sztuki i kultury dla zabytków znajdujących się w granicach Rzeczypospolitej (art. 1). Inwentarz zabytków był rejestrem publicznym,

6 Dz.U. Nr 16, poz. 36.

7 K. Zeidler, M. Marcinowska, Wstęp, w: Dekret Rady Regencyjnej z 1918 r. o opiece nad zabytkami kultury i sztuki z komentarzem, czyli eseje o prawie ochrony dziedzictwa kultury, red. K. Zeidler, M. Marcinowska, Gdańsk 2017, s. 9-10.

8 J. Pruszyński, Dziedzictwo kultury Polski. Jego straty i ochrona prawna, t. 1, Kraków 2001, s. 342. 
podwaliną dzisiejszego rejestru zabytków $z$ art. 7 ustawy o ochronie zabytków. Wpis obiektu do repertorium publicznego stanowił początek jego ochrony prawnej, podczas gdy skreślenie oznaczało jej zakończenie ${ }^{9}$.

Idea inwentaryzacji zabytków jako podstawowej formy ochrony zakorzeniła się w polskim ustawodawstwie i przez długi czas była właściwie jedyną formą ochrony, przyjętą również w Ustawie z dnia 15 lutego 1962 r. o ochronie dóbr kultury ${ }^{10}$ (dalej: u.o.d.k.), już jako wpis do rejestru. Dopiero nowelizacja tego aktu, Ustawą z dnia 19 lipca 1990 r. o zmianie ustawy o ochronie dóbr kultury i o muzeach ${ }^{11}$, poszerzyła katalog form ochrony o nowe sposoby zapewnienia ochrony - wprowadzono uznanie zabytku nieruchomego o szczególnej wartości za pomnik historii (art. 6), a także potraktowano jako formę ochrony wpis do inwentarza muzealiów (art. 4).

Obecnie obowiązująca ustawa o ochronie zabytków i opiece nad zabytkami znacznie poszerzyła katalog form ich ochrony. Zgodnie $z$ art. 7 u.o.z. zaliczamy do nich: 1) wpis do rejestru zabytków, 1a) wpis na Listę Skarbów Dziedzictwa, 2) uznanie za pomnik historii, 3) utworzenie parku kulturowego oraz 4) ustalenie ochrony w miejscowym planie zagospodarowania przestrzennego albo w jednej $\mathrm{z}$ wymienionych $\mathrm{w}$ treści przepisu decyzji administracyjnych ${ }^{12}$. Wśród wskazanych rodzajów ochrony można wyróżnić takie, które faktycznie realizują cel wyznaczony przez ustawodawcę, oraz takie, które $z$ tym celem się mijają.

Nie da się ukryć, że najpopularniejszym i najbardziej efektywnym instrumentem zapewnienia bezpieczeństwa zabytkom pozostaje w dalszym ciągu wpis do rejestru - obecnie jest on prowadzony dla zabytków nieruchomych, ruchomych i archeologicznych. Warto podkreślić, że do rejestru nie wpisuje się zabytku, który jest już wpisany na Listę Skarbów Dziedzictwa, zabytku wpisanego do inwentarza muzeum lub wchodzącego w skład narodowego zasobu

9 Ibidem, s. 150-151.

10 Dz.U. Nr 10, poz. 48.

11 Dz.U. Nr 56, poz. 322.

12 Zob. A. Ginter, A. Michalak, Ustawa o ochronie zabytków i opiece nad zabytkami. Komentarz, Warszawa 2016. 
bibliotecznego ${ }^{13}$. Oprócz tego istotną i mającą szerokie zastosowanie formą ochrony zabytków jest uwzględnienie potrzeby ich ochrony w planie zagospodarowania przestrzennego województw, powiatów i gmin oraz ogólne zobowiązanie, wskazane w art. 18 u.o.z., do uwzględnienia ochrony zabytków i opieki nad zabytkami m.in. przy sporządzaniu i aktualizacji koncepcji przestrzennego zagospodarowania kraju, strategii rozwoju województw, powiatów i gmin, decyzji o warunkach zabudowy czy też decyzji o zezwoleniu na realizację inwestycji drogowej. Należy też zwrócić uwagę, że potrzeba ochrony zabytków stanowi granicę procesów planistycznych, co jest potwierdzone przez art. 1 ust. 2 Ustawy z dnia 27 marca 2003 r. o planowaniu i zagospodarowaniu przestrzennym ${ }^{14}$, gdzie znalazł się katalog szczególnie istotnych wartości, które należy uwzględnić przy działaniach planistycznych, obejmujący potrzeby ochrony dziedzictwa kultury i zabytków ${ }^{15}$.

$Z$ kolei niektóre formy ochrony mają charakter bardziej symboliczny, bez dalej idących skutków, które wzmacniałyby ochronę danego obiektu. Jest tak w przypadku utworzenia parku kulturowego, na obszarze którego można jednak ustanawiać określone zakazy i ograniczenia (art. 17 u.o.z.), co może czynić tę formę ochrony zabytków efektywną, oraz uznania za pomnik historii, któremu poza „tytularnym prestiżem” ustawodawca nie przyznał specjalnego reżimu ochrony. Jedynym działaniem, które w jakiś sposób wyróżnia pomnik historii, jest wspomniana wcześniej możliwość przedstawienia Komitetowi Światowego Dziedzictwa wniosku o wpis takiego obiektu na Listę światowego dziedzictwa UNESCO.

${ }^{13}$ K. Zalasińska, K. Zeidler, Wykład prawa ochrony zabytków, WarszawaGdańsk 2015, s. 94.

14 Dz.U. Nr 80, poz. 717 ze zm.

15 K. Zalasińska, K. Zeidler, Wykład prawa ochrony, s. 108. 


\section{Lista Skarbów Dziedzictwa w ustawie o ochronie zabytków}

Projekt ustawy o zmianie ustawy o ochronie zabytków i opiece nad zabytkami oraz ustawy o muzeach, który wpłynął do Sejmu w 2013 r., przewidział wprowadzenie nowej formy ochrony zabytków - Listy Skarbów Dziedzictwa ${ }^{16}$. Zgodnie $z$ uzasadnieniem nowelizacji forma ta miała po pierwsze zapewniać ochronę najcenniejszych dóbr kultury, które znajdują się w polskich zbiorach, a po drugie stanowić odpowiedź na widoczną w polskim systemie ochrony dziedzictwa kultury sui generis dyskryminację zabytków ruchomych.

W uzasadnieniu wskazano, że projektowana regulacja jest konkretyzacją gwarancji konstytucyjnych - art. 5, który stanowi, że Rzeczpospolita Polska strzeże dziedzictwa narodowego oraz zapewnia ochronę środowiska, kierując się zasadą zrównoważonego rozwoju; art. 6, zgodnie z którym Rzeczpospolita Polska stwarza warunki upowszechniania i równego dostępu do dóbr kultury, będącej źródłem tożsamości narodu polskiego, jego trwania i rozwoju (ust. 1), oraz udziela pomocy Polakom zamieszkałym za granicą w zachowaniu ich związków $\mathrm{z}$ narodowym dziedzictwem kulturalnym (ust. 2), a także art. 73, który przyznaje każdemu wolność korzystania $z$ dóbr kultury ${ }^{17}$.

Podkreślono jednocześnie, że nowy rodzaj ochrony ma dotyczyć tylko zabytków ruchomych. Wynikało to $z$ faktu, że spośród czterech dotychczas funkcjonujących form ochrony zabytków (wpis do rejestru, uznanie za pomnik, utworzenie parku kulturowego oraz ustalenie ochrony w miejscowym planie zagospodarowania przestrzennego lub w jednej $z$ wymienionych decyzji administracyjnych) wszystkie cztery dotyczyły zabytków nieruchomych,

${ }^{16}$ Zob. P. Dobosz, Koncepcja Listy Skarbów Dziedzictwa w systemie prawa ochrony zabytków $w$ Polsce, w: Kultura $w$ praktyce. Zagadnienia prawne, t. 2: Wokót problematyki prawnej zabytków i rynku sztuki, red. A. Jagielska-Burduk, W. Szafrański, Poznań 2013, s. 199-224.

17 Konstytucja Rzeczypospolitej Polskiej z dnia 2 kwietnia 1997 r. (Dz.U. z 1997 r. Nr 78, poz. 483). 
a tylko jeden - wpis do rejestru zabytków - miał zastosowanie do zabytków ruchomych. Taki stan rzeczy w znacznym stopniu ograniczał realizowanie efektywnej ochrony tych zabytków, ponieważ $z$ urzędu wojewódzki konserwator zabytków może dokonać wpisu do rejestru w przypadku, gdy istnieje uzasadniona obawa, że zabytek jest narażony na zniszczenie, uszkodzenie lub utratę (art. 10 ust. 2 u.o.z.). Stąd też pojawiła się potrzeba stworzenia nowego instrumentu ochrony, który będzie obejmował najcenniejsze zabytki ruchome i dodatkowo będzie mógł być realizowany nie tylko na wniosek, ale również z urzędu, przez wyznaczony do tego organ, czyli ministra właściwego do spraw kultury i ochrony dziedzictwa narodowego. Tym samym uprawnienie do objęcia zabytku daną formą ochrony zyskał zupełnie nowy organ, i to organ naczelny, co w pewien sposób wpływa na prestiż samej Listy.

Nowelizacja weszła w życie w 2016 r. pomimo sporów i kontrowersji, które jej towarzyszyły. W dodanym art. 14a ust. 2 zawarto katalog zabytków ruchomych o szczególnej wartości dla dziedzictwa kultury, które mogą uzyskać wpis na Listę Skarbów Dziedzictwa. Wśród nich można wyróżnić m.in. wykonane ręcznie dowolną techniką i na dowolnym materiale dzieła malarstwa, które mają więcej niż 50 lat, ich wartość jest wyższa niż 150000 euro oraz nie są własnością ich twórców (pkt 3), oryginalne rzeźby, posągi lub ich kopie wykonane tą samą techniką co oryginał, które mają więcej niż 50 lat, ich wartość jest wyższa niż 50000 euro oraz nie są własnością ich twórców (pkt 7) czy też pojedyncze lub znajdujące się w zbiorach książki, które mają więcej niż 100 lat i ich wartość jest wyższa niż 50000 euro (pkt 10). Można więc zauważyć, że szczególna wartość zabytku wiąże się nie tylko $z$ wartością duchową i artystyczną, ale przede wszystkim historyczną i ekonomiczną.

Nowelizacja wprowadziła także szereg przepisów dotyczących sposobów ochrony zabytków ujętych na Liście Skarbów Dziedzictwa. W art. 14aa wskazano, że od dnia wszczęcia postępowania w sprawie wpisu zabytku na Listę Skarbów Dziedzictwa do dnia, w którym decyzja w tej sprawie stanie się ostateczna, przy zabytku, którego dotyczy postępowanie, zabrania się prowadzenia prac konserwatorskich i restauratorskich oraz podejmowania innych działań, które mogłyby prowadzić do naruszenia substancji lub 
zmiany wyglądu zabytku. W art. 28 ust. 2 wprowadzono obowiązek zawiadomienia ministra kultury i dziedzictwa narodowego przez właściciela lub posiadacza zabytku wpisanego na Listę o uszkodzeniu, zniszczeniu lub utracie zabytku, a także możliwym zagrożeniu dla niego oraz zmianie miejsca jego przechowywania. Znowelizowany art. 29 ust. 3 wprowadził $z$ kolei obowiązek udostępniania do badań zabytku wpisanego na Listę, a podmiotem właściwym w tym zakresie jest minister kultury i dziedzictwa narodowego.

W kompetencjach ministra leży także wydawanie pozwolenia na prowadzenie przy zabytku wpisanym na Listę Skarbów Dziedzictwa prac konserwatorskich i restauratorskich oraz badań konserwatorskich (art. 36 ust. 1a). Zgodnie $z$ uzasadnieniem do projektu ustawy ograniczenie dopuszczalnych działań przy zabytku wpisanym na Listę miało na celu umożliwienie stosowania tylko takich zabiegów, które zmierzają do utrwalenia i utrzymania w jak najlepszym stanie substancji zabytku.

Specyficzny zakres ochrony zabytków znajdujących się na Liście Skarbów Dziedzictwa obejmuje również reguły przechowywania i przewożenia takich obiektów. Zgodnie $z$ art. 37i zabytek wpisany na Listę przechowuje się w pomieszczeniu wyposażonym w zabezpieczenia techniczne na wypadek kradzieży, pożaru i innych zagrożeń lub mającym zapewnioną bezpośrednią stałą ochronę fizyczną, a projekt zabezpieczeń uzgadnia się $z$ ministrem kultury i dziedzictwa narodowego. Szczegółowe uregulowanie tej kwestii zostało zawarte w Rozporządzeniu Ministra Kultury i Dziedzictwa Narodowego $z$ dnia 21 maja 2018 r. w sprawie wymagań, jakim powinna odpowiadać ochrona przechowywanego i przewożonego zabytku wpisanego na Listę Skarbów Dziedzictwa ${ }^{18}$.

18 Dz.U. poz. 1134. 


\section{Kontrowersje związane $z$ Listą Skarbów Dziedzictwa}

Jak wspomniano wcześniej, Lista Skarbów Dziedzictwa ma dwojakie korzenie. Rozpatrując całokształt okoliczności jej powstawania, można dojść do wniosku, że za „kurtyną” głównego celu, wskazanego w uzasadnieniu do projektu ustawy, ukrywa się inny cel, który faktycznie był impulsem do podjęcia prac nad tą formą ochrony. Chodziło mianowicie o „przywiązanie” najcenniejszych dzieł sztuki, w tym przede wszystkim obrazu Leonarda Da Vinci Dama z łasiczka (lub Dama z gronostajem), do ich miejsca przechowywania, które jest w kraju, i sprawowanie nad nimi permanentnej i bezwzględnej kontroli.

Idea ta zrodziła się w efekcie toczących się przez wiele lat sporów między muzealnikami, konserwatorami i historykami sztuki a Fundacją Książąt Czartoryskich w związku $\mathrm{z}$ wypożyczaniem obrazu włoskiego mistrza (na którym Fundacja zarabiała, przy jednoczesnym unikaniu kosztów utrzymania obrazu, które ponosiło Muzeum Narodowe w Krakowie jako depozytariusz obrazu). Punktem zapalnym w tym konflikcie było „zablokowanie” przez Ministerstwo Kultury i Dziedzictwa Narodowego (MKiDN), na wniosek krakowskiego muzeum, wysłania Damy z łasiczką na wystawę w Berlinie ${ }^{19}$. Obraz został wystawiony w 2010 r. na Zamku Królewskim w Warszawie w ramach ekspozycji poświęconej największym dziełom ze zbiorów książąt Czartoryskich. Po zakończeniu wystawy arcydzieło Leonarda Da Vinci nie wróciło jednak do Krakowa, tylko zgodnie ze stanowiskiem władz Fundacji miało pozostać w Warszawie do czasu jego wysłania do Londynu na wystawę w National Gallery. Wywołało to oburzenie po stronie Muzeum Narodowego w Krakowie, które ze wparciem MKiDN postanowiło położyć kres tak częstym podróżom Damy z łasiczką, narażającym obraz na niebezpieczeństwo (warto wspomnieć, że prawdopodobnie najsłynniejsze dzieło włoskiego malarza Mona Lisa ma zakaz „opuszcza-

${ }^{19}$ http://www.magazynsztuki.pl/dama-z-lasiczka-na-linii-sporu/ (dostęp: 6.12.2020 r.). 
nia” Luwru) ${ }^{20}$. Stąd też pojawił się pomysł stworzenia takiej formy ochrony, która po pierwsze będzie obejmowała tylko najcenniejsze dzieła w polskich zbiorach, po drugie będzie podlegała ministrowi kultury i dziedzictwa narodowego i po trzecie będzie wymagała uzyskania zgody ministra na jednorazowy, czasowy wywóz za granicę obiektu objętego ochroną, a wywóz stały oraz wielokrotny czasowy wywóz nie będą możliwe.

Inicjatywa utworzenia Listy Skarbów Dziedzictwa wzbudzała kontrowersje już na etapie prac legislacyjnych. Pojawiły się wątpliwości, które dotyczyły przede wszystkim kolizji przepisów dotyczących Listy Skarbów Dziedzictwa $z$ prawem własności oraz naruszenia zasad poprawnej legislacji ${ }^{21}$. Część $z$ nich była podważana przez projektodawców, którzy argumentowali, że taka sama regulacja jak ta dotycząca Listy jest stosowana wobec zabytków ruchomych wpisywanych do rejestru zabytków przez wojewódzkiego konserwatora zabytków, a jedyną zmianą jest nowy podmiot dokonujący wpisu na Listę, co uzasadniano szczególnie istotnym charakterem obiektów mających się na niej znaleźć ${ }^{22}$.

Wątpliwości, które się pojawiły, spowodowały, że Prezydent RP wystąpił $z$ wnioskiem do Trybunału Konstytucyjnego o zbadanie zgodności z Konstytucją RP przepisów analizowanej regulacji ${ }^{23}$. We wniosku po pierwsze zakwestionowano możliwość przejęcia, za odszkodowaniem, zabytku ruchomego wpisanego na Listę Skarbów Dziedzictwa na własność Skarbu Państwa, a po drugie zwrócono uwagę na nieostrość kryteriów decydujących o wpisie obiektu na Listę, co jest niezgodne z zasadami przyzwoitej legislacji.

20 Ibidem.

21 Zob. Lista Skarbów Dziedzictwa niezgodna z Konstytucją?, https:// dziennikpolski24.pl/lista-skarbow-dziedzictwa-niezgodna-z-konstytucja/ ar/5753375 (dostęp: 19.06.2021 r.).

22 A. Lizak, Czy potrzebne są nowe formy ochrony zabytków? Wybrane uwagi w kontekście utworzenia Listy Skarbów Dziedzictwa, „Nowa Muzeologia” 2017, t. 2, s. 202.

23 Zob. wniosek Prezydenta RP do Trybunału Konstytucyjnego z dnia 31 lipca 2015 r. o zbadanie zgodności z Konstytucją ustawy z dnia 10 lipca 2015 r. o zmianie ustawy o ochronie zabytków i ustawy o muzeach. 
Na gruncie prawa ochrony zabytków permanentnie występuje konflikt wartości pomiędzy interesem jednostki (właściciela lub posiadacza zabytków) a dobrem wspólnym (dziedzictwo kultury stanowi ważny interes publiczny rangi konstytucyjnej). Spór ten we współczesnej filozofii prawa określany jest mianem sporu liberalizm versus komunitaryzm ${ }^{24}$. Liberalizm i komunitaryzm zakładają odmienne postrzeganie porządku społecznego. Naczelną wartością leżącą u podstaw liberalizmu jest wolność jednostki i ochrona jej praw, w tym również ochrona prawa własności. Prawo własności jest najszerszym prawem podmiotowym jednostki, w związku z czym ograniczenie tego prawa może nastąpić tylko wówczas, jeśli zostaną spełnione wymagania, jakie stawia Konstytucja RP w art. 31 ust. 3 oraz w art. 64 ust. 3, czyli ograniczenie może być ustanowione tylko w ustawie i tylko wtedy, gdy jest to konieczne w demokratycznym państwie dla jego bezpieczeństwa lub porządku publicznego, i tylko $\mathrm{w}$ zakresie, w jakim nie narusza to istoty prawa własności. $Z$ kolei komunitaryści traktują społeczeństwo jako wspólnotę, w ramach której jednostka egzystuje i realizuje swoje cele i wobec której ma ona zobowiązania ${ }^{25}$. Ochrona i dbanie o dobro wspólne jest więc podstawową rolą jednostki w społeczeństwie.

$\mathrm{W}$ prawie ochrony dziedzictwa kultury ingerencji w prawa właściciela można dostrzec wiele. Podstawowym ich przejawem jest tzw. dyskrecjonalna władza konserwatorska, czyli możliwość wydawania przez konserwatorów zabytków decyzji administracyjnych, ingerujących $\mathrm{w}$ prawo własności zabytku w celu ochrony dobra wspólnego ${ }^{26}$. Oprócz tego mamy szereg przepisów, które wyznaczają obowiązki właściciela lub posiadacza względem zabytku ${ }^{27}$ oraz wprowadzają ograniczenia w dysponowaniu nim ${ }^{28}$.

${ }^{24} \mathrm{~K}$. Zeidler, Ograniczenia prawa własności $w$ świetle sporu liberalizmu z komunitaryzmem, „Gdańskie Studia Prawnicze” 2016, t. 36, s. 538; zob. L. Morawski, Główne problemy współczesnej filozofii prawa. Prawo $w$ toku przemian, Warszawa 2000, s. 125 i n.

25 K. Zeidler, Ograniczenia prawa własności, s. 540.

26 Zob. E. Kowalska, Własność zabytku a dyskrecjonalna władza konserwatorska, Gdańsk 2018.

27 Zob. art. 5, 28, 29, 30 u.o.z.

28 Zob. art. 36 u.o.z. 
Spór liberalizmu $\mathrm{z}$ komunitaryzmem objawia się $\mathrm{w}$ obu fenomenach prawa, czyli zarówno przy jego tworzeniu, jak i stosowaniu ${ }^{29}$. Warto $\mathrm{w}$ tym miejscu dodać, że to właśnie w procesie stosowania prawa najczęściej dochodzi do sporu konstytucyjnego, co tworzy tzw. hard case $\mathrm{w}$ prawie ${ }^{30}$. $\mathrm{Z}$ takim sporem mamy także do czynienia w rozważanym przypadku. Zgodnie ze stanowiskiem wnioskodawcy, czyli Prezydenta RP, przepisy dotyczące Listy Skarbów Dziedzictwa były niezgodne $z$ art. 2 Konstytucji RP i $z$ postanowieniami zawartymi w art. 64 ust. 1 i 3 oraz art. 31 ust. 3 Konstytucji RP.

Prezydent RP w swoim wniosku stwierdził, że kwestionowana regulacja, w tym możliwość dokonania wpisu na Listę nie tylko na wniosek, ale również $z$ urzędu, oraz nieprecyzyjność cech, na podstawie których taki wpis jest dokonywany, istotnie wpływa na korzystanie $z$ konstytucyjnego prawa do własności, a ponadto umożliwia zbyt daleko idącą dowolność organu administracji w podejmowaniu decyzji o wpisie na Listę Skarbów Dziedzictwa ${ }^{31}$. Stąd też w ocenie wnioskodawcy wątpliwości budzi także możliwość przejęcia przez ministra kultury i dziedzictwa narodowego zabytku ruchomego na własność, za odszkodowaniem w wysokości wartości rynkowej zabytku, ponieważ w świetle przepisów nie ma możliwości precyzyjnego ustalenia, w jakich sytuacjach dopuszczalna jest ingerencja organów w prawo własności. Co więcej, takie przymusowe pozbawienie własności właściciela zabytku ruchomego jest ingerencją w istotę tego prawa, co wykracza poza konstytucyjnie wymaganą proporcjonalność ograniczenia. We wniosku wspomniano również, że wycena zabytku dokonywana celem wypłaty odszkodowania może być niewymierna wobec szczególnej wartości emocjonalnej rzeczy, nadawanej na podstawie wspomnień i uczuć $\mathrm{z}$ nią związanych ${ }^{32}$.

29 K. Zeidler, Ograniczenia prawa własności, s. 540-541.

30 Zob. K. Zeidler, Hard cases we wspótczesnej filozofii prawa, w: idem, Restytucja dóbr kultury ze stanowiska filozofii prawa. O trudnych przypadkach na granicy kultury i prawa, Warszawa 2011, s. 29 i n.

31 Wniosek Prezydenta RP do Trybunału Konstytucyjnego, s. 5-7.

32 A. Lizak, Czy potrzebne są nowe formy ochrony zabytków?, s. 203. 
Również przedstawiciele doktryny zabrali głos w sprawie nowelizacji ${ }^{33}$, stwierdzając, że istotną jej wadą jest brak definicji legalnej „skarbu dziedzictwa”" ${ }^{4}$. Jak wiadomo, już sama definicja zabytku, która znalazła się w art. 3 u.o.z., budzi wątpliwości interpretacyjne, a wprowadzenie niewyjaśnionego pojęcia skarbu dziedzictwa dodatkowo komplikuje proces stosowania prawa i stawia potencjalnych adresatów prawa $\mathrm{w}$ sytuacji braku pewności w prawie. Tworzy się więc Listę Skarbów Dziedzictwa, nie odpowiadając w sposób normatywny na pytanie, co tym skarbem dziedzictwa jest, a to $z$ kolei może skutkować możliwością ingerencji organu państwa w sposób uznaniowy w prawa właściciela lub posiadacza zabytku ${ }^{35}$. Również zwrot „o szczególnej wartości dla kultury” jest niedookreślony i za mało precyzyjny, by móc usunąć ten stan niepewności w prawie. Inną kwestią podawaną w wątpliwość przez doktrynę jest możliwość wydania decyzji o wpisie zabytku ruchomego na Listę Skarbów Dziedzictwa nie tylko na wniosek, ale również z urzędu. Także ta regulacja pociąga za sobą szereg istotnych ograniczeń prawa własności i może w sposób szczególny godzić w interes jednostki, począwszy od zakazu wywozu takiego zabytku za granicę, aż do wywłaszczenia. Najpoważniejsze wątpliwości budzi jednak możliwość przejęcia zabytku wpisanego na Listę przez państwo, czyli sui generis nacjonalizacja ${ }^{36}$, np. w sytuacji, gdy właściciel nie będzie w stanie zapewnić zabytkowi wskazanych w art. 37a warunków przechowywania. Jest to bardzo prawdopodobne, gdyż spełnienie ustawowych obowiązków nałożonych na właściciela lub posiadacza zabytku wpisanego na Listę jest bardzo kosztowne i nawet

${ }^{33}$ Zob. wypowiedzi K. Zeidlera i W. Szafrańskiego, https://prawo.gazetaprawna.pl/artykuly/887012, prezydent-wysyla-przepisy-o-zabytkach-do-trybunalu.html (dostęp: 19.06.2021 r.).

${ }^{34}$ K. Zeidler, Ograniczenia prawa własności, s. 546 i n.; zob. idem, Opinia prawna $w$ zakresie konstytucyjności przepisów ustawy z dnia 10 lipca 2015 r. o zmianie ustawy o ochronie zabytków i opiece nad zabytkami oraz ustawy o muzeach odnośnie do regulacji wprowadzającej Listę Skarbów Dziedzictwa przygotowana dla Fundacji XX. Czartoryskich $w$ Krakowie, s. 5 i n. (opinia prawna udostępniona autorce do wglądu przez K. Zeidlera).

35 Ibidem.

36 Ibidem. 
możliwość uzyskania dotacji celowej nie zawsze te koszty pokryje. W efekcie tego może dojść do sytuacji, w której zostaną spełnione przesłanki wywłaszczenia i właściciel lub posiadacz zabytku wpisanego na Listę zostanie pozbawiony swojego prawa własności ${ }^{37}$.

Stanowiska wnioskodawcy oraz przedstawicieli doktryny nie podzielił Trybunał Konstytucyjny. W wyroku z dnia 25 maja 2016 r. nie stwierdził on niezgodności $z$ Konstytucją RP kwestionowanych przepisów $^{38}$. Przede wszystkim Trybunał nie uznał zaskarżonych przepisów za sprzeczne $z$ art. 2 Konstytucji RP i odwołując się do kryteriów ustalonych $w$ innych orzeczeniach TK, uznał je za precyzyjne i komunikatywne. Wskazał, że konstrukcja językowa przepisów pozwala na jednoznaczne sprecyzowanie adresata normy, kompetencji, podmiotu, którego obowiązki dany przepis kreuje, oraz okoliczności ważnych dla dokonania czynności konwencjonalnej ${ }^{39}$. Głębsze rozważania Trybunał poświęcił ocenie klauzuli generalnej „o szczególnej wartości dla dziedzictwa kulturowego”, faktycznie będącej zwrotem niedookreślonym. Trybunał powołał się tutaj na wyrok zapadły w sprawie SK 5/99, w którym stwierdzono, że nie da się nigdy całkowicie wyeliminować tych zwrotów $z$ przepisów prawa obowiązującego ${ }^{40}$, ale również na orzeczenie $\mathrm{K} 8 / 08$, z którego wynika, że ustawodawca powinien posługiwać się klauzulami generalnymi jedynie w ostateczności, gdy nie ma możliwości uniknięcia takiego rozwiązania ${ }^{41}$. Według Trybunału taka sytuacja zaistniała w analizowanej sprawie, ponieważ regulacja Listy Skarbów Dziedzictwa dotyczy specyficznej materii i nie jest możliwe posłużenie się precyzyjnymi, kazuistycznymi określeniami. Co więcej, wskazał on, że wyrażenie „o szczególnej wartości dla dziedzictwa kulturo-

37 Ibidem.

38 Wyrok TK $z$ dnia 25 maja 2016 r., Kp 2/15, OTK ZU nr A/2016, poz. 23.

39 Zob. A. Lizak, Glosa do wyroku Trybunału Konstytucyjnego z dnia 25 maja 2016 roku (sygn. akt Kp 2/15, OTK ZU nr A/2016, poz. 23), „Santander Art and Culture Law Review" 2017, nr 1(3), s. 159-174.

40 Wyrok TK z dnia 17 października 2000 r., SK 5/99, OTK ZU nr 7/2000, poz. 254.

41 Wyrok TK z dnia 18 marca 2010 r., K 8/08, OTK ZU nr 3/A/2010, poz. 23. 
wego" zawęża zakres zabytków ruchomych podlegających wpisowi, a dodatkowo ustawodawca w art. 64 ust. 1 u.o.z. zawarł katalog kategorii zabytków mogących ubiegać się o wpis, co wystarczająco wyznacza granicę decyzji organu administracji ${ }^{42}$.

Trybunał Konstytucyjny nie dopatrzył się również niezgodności przepisów dotyczących Listy Skarbów Dziedzictwa $z$ art. 64 oraz art. 31 ust. 3 ustawy zasadniczej. W tej części wyroku już na wstępie Trybunał wskazał, że wnioskodawca nie podał żadnych argumentów, dlaczego w jego ocenie art. 14a ust. 2 u.o.z. jest niezgodny $z$ art. 64 Konstytucji RP, a jedynie ograniczył się do wyliczenia obowiązków ciążących na właścicielu zabytku wpisanego na Listę. W braku uzasadnienia TK postanowił umorzyć postępowanie w tym zakresie. W odniesieniu do nowego art. 50 ust. 4 u.o.z. i możliwości ograniczenia praw własności właściciela zabytku wpisanego na Listę oraz zgodności tej regulacji $z$ art. 64 ust. 1 i $3 \mathrm{w}$ związku $z$ art. 31 ust. 3 Konstytucji RP, Trybunał wskazał, że zapewnienie efektywnej ochrony zabytków o szczególnym znaczeniu narodowym jest jednym $z$ celów konstytucyjnych, o których traktuje już preambuła, a $z$ racji tego, że mamy do czynienia z zabytkami „o szczególnej wartości dla dziedzictwa kulturowego”, liczba i zakres obowiązków nałożonych na właściciela takiego zabytku nie stanowią nadmiernego ograniczenia prawa własności ${ }^{43}$. Dodał również, że samo wywłaszczenie zabytku wpisanego na Listę Skarbów Dziedzictwa zostało celowościowo uwarunkowane przez ustawodawcę, gdyż może ono nastąpić „z przeznaczeniem na cele kultury", więc nie może stanowić narzędzia polityki organów władzy publicznej lub środka służącego powiększaniu majątku Skarbu Państwa i ponadto następuje za odszkodowaniem w wysokości ceny rynkowej zabytku, która jest właściwą podstawą określenia odszkodowania słusznego ${ }^{44}$.

42 Wyrok TK z dnia 25 maja 2016 r., s. 14-16.

43 Zob. A. Górska, Glosa do wyroku Trybunału Konstytucyjnego z 25 maja 2016 roku (sygn. akt Kp 2/15, OTK ZU nr A/2016, poz. 23), „Santander Art and Culture Law Review” 2017, nr 1(3), s. 175-188.

44 Wyrok TK z dnia 25 maja 2016 r., s. 26 i n. 
Tym samym Trybunał nie stwierdził kolizji przepisów zmieniających ustawę o ochronie zabytków z przepisami Konstytucji RP, a sam wyrok przesądził o uznaniu Listy Skarbów Dziedzictwa za nową formę ochrony zabytków.

\section{Lista Skarbów Dziedzictwa w praktyce, czyli o martwym prawie}

W tym miejscu należy się zastanowić, jak kształtuje się funkcjonowanie Listy Skarbów Dziedzictwa w praktyce - po 5 latach od uchwalenia nowelizacji. Jak wynika $z$ Rozporządzenia Ministra Kultury i Dziedzictwa Narodowego w sprawie Listy Skarbów Dziedzictwa, Lista ta prowadzona jest w systemie teleinformatycznym udostępnionym w Biuletynie Informacji Publicznej na stronie Ministra Kultury i Dziedzictwa Narodowego (§ 2). Po wejściu na stronę Biuletynu na próżno jednak jej szukać, ponieważ Listy finalnie nie utworzono, więc istnieje ona tylko jako teoretyczny instrument w ustawie o ochronie zabytków. Stąd też pojawia się pytanie, czy jest to forma ochrony w ogóle potrzebna, skoro minęło tyle czasu, a nie znajduje się na niej ani jeden zabytek.

Założeniem ustawodawcy, tak jak wspomniano wcześniej, było po pierwsze zapewnienie specjalnej ochrony dziełom szczególnie istotnym dla polskiego dziedzictwa kultury, a po drugie generalne wzmocnienie ochrony zabytków ruchomych. Najwidoczniej jednak ustawodawca nie wziął pod uwagę, że tak cenne zabytki znajdują się w większości w muzeach, a co za tym idzie - korzystają $z$ formy ochrony przewidzianej przez Ustawę z dnia 21 listopada 1996 r. o muzeach ${ }^{45}$ (dalej: u.m.), czyli wpisu do inwentarza muzealiów, co w wystarczający sposób zabezpiecza takie obiekty.

Aby zobrazować podobieństwo w praktycznej doniosłości obu form ochrony, można chociażby stwierdzić, że zarówno wpis do inwentarza muzealiów, jak i wpis na Listę Skarbów Dziedzictwa rodzi szereg podobnych obowiązków związanych $\mathrm{z}$ zapewnieniem odpowiedniego zabezpieczenia obiektu przed pożarem, kradzieżą

${ }^{45}$ Dz.U. z 1997 r. Nr 5, poz. 24 ze zm. 
i innym niebezpieczeństwem grożącym ich zniszczeniem lub utratą, a także $z$ dostosowaniem pomieszczenia, w którym obiekt się znajduje, i zapewnieniem odpowiednich warunków sposobu i trybu przenoszenia obiektu, $z$ uwzględnieniem jego specyfiki. Co więcej, w obu przypadkach zakazany jest wywóz obiektu za granicę na stałe, a wywóz czasowy wymaga zgody odpowiedniego podmiotu.

Jak można więc zauważyć, mechanizmy ochronne Listy Skarbów Dziedzictwa są poniekąd kalką mechanizmów występujących przy wpisie do inwentarza muzealiów, co może podważać sens tej nowej formy ochrony. Jedynym przypadkiem, w którym faktycznie Lista stanowiłaby potrzebny i przede wszystkim skuteczny instrument, zapewniający ochronę zabytkom ruchomym o szczególnym znaczeniu, byłaby sytuacja, gdyby dany obiekt, znajdujący się w rękach prywatnych, wraz z upływem czasu zyskał charakter umożliwiający przyporządkowanie go do jednej kategorii zabytków, które mogą zostać wpisane na Listę i tym samym korzystać z ochrony, którą ten wpis gwarantuje. Idea przyświecająca utworzeniu Listy Skarbów Dziedzictwa zasługuje na uznanie, a zapewne wzmocnienie ochrony zabytków ruchomych jest potrzebne. Pojawia się jednak pytanie, czy nie lepiej, zamiast wprowadzać nowe instrumenty ochrony prawnej, ulepszać te istniejące już w systemie prawnym.

Lista Skarbów Dziedzictwa jawi się obecnie jako ochrona pozorna, realizowana tylko na poziomie treści norm prawnych, bez ich faktycznego stosowania. Stąd też można wysunąć postulat, aby kłaść większy nacisk na proces egzekwowania, stosowania i ulepszania prawa już obowiązującego, zamiast tworzyć nowe regulacje, które będą tylko utrwalać fikcję ochrony normatywnej zabytków - w szczególności, że zabytek wpisany na Listę Skarbów Dziedzictwa jest skreślany $z$ rejestru zabytków ruchomych. Sprawia to, że ochrona zabytków mających szczególną wartość, która powinna być ochroną wzmocnioną, jest ochroną konkurencyjną, wykluczającą się z podstawową formą ochrony, jaką jest wpis do rejestru zabytków. Może to prowadzić do swoistego dualizmu ochrony zabytków ruchomych. Dodatkowo, biorąc również pod uwagę fakt, że najcenniejsze dzieła, które znajdują się w zbiorach muzealnych, korzystają z mechanizmów ochronnych, jakie zapewnia wpis do inwentarza muzealiów, Lista Skarbów Dziedzictwa jawi się jako 
niepotrzebna forma ochrony zabytków. Co więcej, kontrowersje, które towarzyszyły powstawaniu Listy, wciąż pozostają zasadne i aktualne. Ustawodawca wobec tego powinien ponownie rozważyć ideę i obecną konstrukcję Listy Skarbów Dziedzictwa i albo udoskonalić przepisy jej dotyczące, albo całkowicie wyeliminować tę formę ochrony zabytków i skupić się na ulepszaniu pozostałych, funkcjonujących już instrumentów ochrony, skoro minęło tyle lat, a Lista nadal nie powstała. Może też warto rozważyć zmianę charakteru tej ochrony na wzór państw zachodnioeuropejskich czy dostosować ją do regulacji prawa Unii Europejskiej. Te kwestie pozostają cały czas otwarte.

\section{STRESZCZENIE}

\section{Lista Skarbów Dziedzictwa - niepotrzebna forma ochrony zabytków?}

Analizując zmiany polskiego prawa, poświęconego ochronie dziedzictwa kultury, można odnieść wrażenie, że ustawodawca konsekwentnie dąży do zapewnienia wzmożonej i efektywnej ochrony zabytków poprzez stopniowe poszerzanie katalogu form ich ochrony.

Możliwe prawne formy ochrony są uregulowane w Ustawie $z$ dnia 23 lipca 2003 r. o ochronie zabytków i opiece nad zabytkami, a stosunkowo nowym rozwiązaniem jest wpis na Listę Skarbów Dziedzictwa, wprowadzony nowelizacją z 2016 r. Lista jednak od samego początku budzi wiele kontrowersji, a jej geneza ma dwojakie korzenie. $Z$ jednej strony jest odpowiedzią na jeden $z$ podstawowych problemów systemu ochrony zabytków w Polsce, czyli sui generis dyskryminację zabytków ruchomych, a z drugiej powołanie do życia Listy Skarbów Dziedzictwa było efektem sporów, które przez wiele lat toczyły się między muzealnikami, konserwatorami i historykami sztuki a Fundacją Czartoryskich z powodu wypożyczania obrazu Leonarda da Vinci Dama $z$ łasiczka na wystawy za granicą.

Snując rozważania dotyczące Listy Skarbów Dziedzictwa, należy się zastanowić, jak kształtuje się funkcjonowanie Listy w praktyce oraz czy na pewno jest to forma potrzebna w naszym systemie prawnej ochrony zabytków.

Słowa kluczowe: Lista Skarbów Dziedzictwa; zabytki; ochrona zabytków; dziedzictwo kultury; prawo ochrony zabytków 


\section{SUMMARY \\ List of Heritage Treasures - unnecessary form of heritage protection?}

When analyzing the changes in Polish law devoted to the protection of cultural heritage, one can get the impression that the legislator consistently strives to ensure increased and effective protection of monuments by gradually expanding the catalog of forms of their protection.

Possible legal forms of protection are regulated in the Act of 23 July 2003 on the protection and care of monuments, and a relatively new solution is the entry on the List of Heritage Treasures, introduced by the 2016 amendment. However, the list has been controversial from the very beginning, and its genesis has two roots. On the one hand, it is a response to one of the basic problems of the monument protection system in Poland, i.e. sui generis discrimination of movable monuments, and on the other - the establishment of the List of Heritage Treasures was the result of disputes that had been going on for many years between museum professionals, conservators and art historians, and the Princes Czartoryski Foundation for lending Leonardo da Vinci's painting Lady with an Ermine for exhibitions abroad.

While reflecting on the List of Heritage Treasures, one should consider how the List of Heritage Treasures is shaped in practice and whether it is really a form necessary in our system of legal monument protection.

Keywords: List of Heritage Treasures; monuments; protection of cultural heritage; cultural heritage; cultural heritage law

\section{BIBLIOGRAFIA}

Dobosz P., Ewoluujące prawne formy ochrony zabytków $w$ Polsce, w: Prawo ochrony zabytków, red. K. Zeidler, Warszawa-Gdańsk 2014.

Dobosz P., Koncepcja Listy Skarbów Dziedzictwa w systemie prawa ochrony zabytków $w$ Polsce, w: Kultura $w$ praktyce. Zagadnienia prawne, t. 2: Wokót problematyki prawnej zabytków i rynku sztuki, red. A. Jagielska-Burduk, W. Szafrański, Poznań 2013.

Ginter A., Michalak A., Ustawa o ochronie zabytków i opiece nad zabytkami. Komentarz, Warszawa 2016. 
Górska A., Glosa do wyroku Trybunału Konstytucyjnego z 25 maja 2016 roku (sygn. akt Kp 2/15, OTK ZU nr A/2016, poz. 23), „Santander Art \& Culture Law Review" 2017, nr 1(3).

Kowalska E., Własność zabytku a dyskrecjonalna władza konserwatorska, Gdańsk 2018.

Lizak A., Czy potrzebne są nowe formy ochrony zabytków? Wybrane uwagi $w$ kontekście utworzenia Listy Skarbów Dziedzictwa, „Nowa Muzeologia” 2017, t. 2.

Lizak A., Glosa do wyroku Trybunału Konstytucyjnego z dnia 25 maja 2016 roku (sygn. akt Kp 2/15, OTK ZU nr A/2016, poz. 23), „Santander Art and Culture Law Review” 2017, nr 1(3).

Morawski L., Główne problemy współczesnej filozofii prawa. Prawo $w$ toku przemian, Warszawa 2000.

Pruszyński J., Dziedzictwo kultury Polski. Jego straty i ochrona prawna, t. 1, Kraków 2001.

Zalasińska K., Zeidler K., Wykład prawa ochrony zabytków, WarszawaGdańsk 2015.

Zeidler K., Hard cases we współczesnej filozofii prawa, w: K. Zeidler, Restytucja dóbr kultury ze stanowiska filozofii prawa. O trudnych przypadkach na granicy kultury i prawa, Warszawa 2011.

Zeidler K., Ograniczenia prawa własności $w$ świetle sporu liberalizmu z komunitaryzmem, „Gdańskie Studia Prawnicze” 2016, t. 36.

Zeidler K., Opinia prawna w zakresie konstytucyjności przepisów ustawy z dnia 10 lipca 2015 r. o zmianie ustawy o ochronie zabytków i opiece nad zabytkami oraz ustawy o muzeach odnośnie do regulacji wprowadzającej Listę Skarbów Dziedzictwa przygotowana dla Fundacji XX. Czartoryskich $w$ Krakowie.

Zeidler K., Marcinowska M. (red.), Dekret Rady Regencyjnej z 1918 r. o opiece nad zabytkami kultury i sztuki z komentarzem, czyli eseje o prawie ochrony dziedzictwa kultury, Gdańsk 2017. 